\title{
Cultural Guidelines for Commercial Production of Boston Fern (Nephrolepsis exaltata 'Bostoniensis') ${ }^{1}$
}

\author{
Bill Schall, Heqiang Huo, and Jianjun Chen ${ }^{2}$
}

\section{Introduction}

Nephrolepis exaltata (L.) Schott, commonly known as sword fern, is native to North, Central, and South America, the West Indies, and Africa (Griffith 2006). The fronds are rigid and erect, $50-150 \mathrm{~cm}$ long, and $7-15 \mathrm{~cm}$ wide. The pinnae are close. The fronds form a rosette and the plant has a compact, upright form (Hvoslef-Eide 1991). The wild sword fern was cultivated as a house plant. In 1895, a mutant exhibiting gracefully arching fronds was discovered in Boston (Blaydes 1940). Due to its improved ornamental value and more tolerance to indoor environmental conditions, the mutant was named as N. exaltata 'Bostoniensis' and quickly gained its popularity as Boston fern. Since then, many cultivars have been selected from 'Bostoniensis', and Boston fern cultivars have almost entirely replaced the wild species and become one of the most important foliage crops in the ornamental plant industry (Henny and Chen 2003). Boston fern varieties take many forms and are prized for their curly, wavy, arching, double-pinnate, and overlapping fronds. Some larger Boston fern cultivars are grown outdoors in Florida landscapes as a ground cover in shady areas where winter permits. Smaller, more ornate varieties are grown in containers as potted plants or hanging baskets for interiorscaping. This article describes common Boston fern cultivars in the foliage industry, provides guidelines for their culture and interior use, and lists physiological problems that may be encountered during production and interiorscape use (Figure 1).
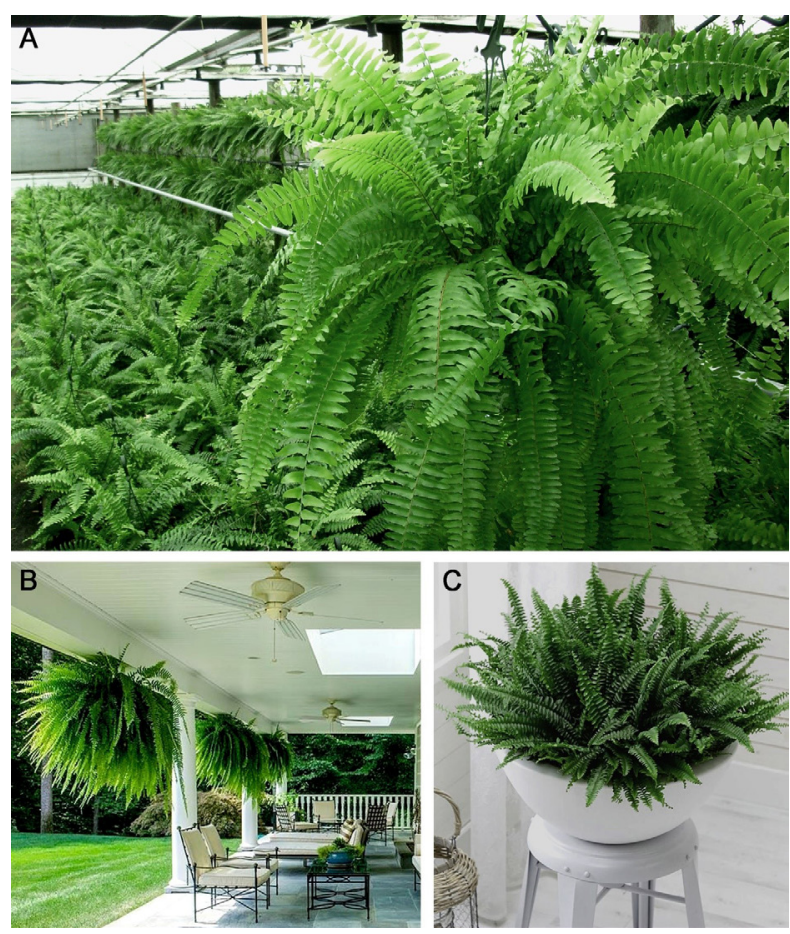

Figure 1. Boston fern production and use as an indoor foliage plant; shaded greenhouse production of Boston fern as potted plants on ground and as hanging baskets. Credits: Jianjun Chen, UF/IFAS

\section{Cultivars}

Major Boston fern cultivars are listed in Table 1. The selection of cultivars should be based on whether the crop is intended for landscape or interiorscape usage. The final plant size and growth habit will determine how the crop

1. This document is ENH1286, one of a series of the Environmental Horticulture Department, UF/IFAS Extension. Original publication date January 2018. Visit the EDIS website at http://edis.ifas.ufl.edu.

2. Bill Schall, Extension agent IV, UF/IFAS Extension Palm Beach County, West Palm Beach, FL 33415; Heqiang Huo, assistant professor, Mid-Florida Research and Education Center, UF/IFAS Extension, Apopka, FL 32703; and Jianjun Chen, professor, Mid-Florida Research and Education Center, UF/ IFAS Extension, Apopka, FL 32703.

The Institute of Food and Agricultural Sciences (IFAS) is an Equal Opportunity Institution authorized to provide research, educational information and other services only to individuals and institutions that function with non-discrimination with respect to race, creed, color, religion, age, disability, sex, sexual orientation, marital status, national origin, political opinions or affiliations. For more information on obtaining other UF/IFAS Extension publications, contact your county's UF/IFAS Extension office. 
is handled throughout production (Kessler 2001). Larger varieties are well-suited to landscape use or application for a porch hanging basket or parlor fern. Smaller, finetextured cultivars are well suited as attractive foliage plants, but may develop growth problems under low light and humid conditions due to their dense foliage.

Growers should be aware that other sword ferns, such as tuberous sword fern (Nephrolepis cordifolia) and Asian sword fern (Nephrolepis multiflora), are non-native to Florida and are listed as Florida's most invasive species in category I and II, respectively (Landeland 2014).

\section{Cultural Guidelines}

\section{Propagation}

Historically, Boston ferns were propagated by dividing older plants grown in stock beds outdoors (Henley 1991). Propagation using greenhouse-grown stock maintained on raised benches or in hanging baskets provides maximum environmental control and better sanitation. Growers start either with plantlets pulled or divided from stock plants, or they use liners started in plug trays. Today, a majority of Boston fern cultivars are propagated through tissue culture and sold in 72-, 98-, or 162-cell trays.

\section{Containers}

Tissue culture liners are usually potted in small pots first. For example, plugs from 72-cell trays should be transplanted into 4 -inch pots and grown for 6-8 weeks to reach a good size, and then transplanted to a 10-inch or larger pot. This is generally good technique for many plants, but more critical for some for Boston ferns. Final selection of containers depends on plant size; large containers are used for growing large-sized cultivars and smaller containers are used for small-sized cultivars. Plants intended for landscape use are generally potted directly into 3-gallon size utility pots for growing on in a shadehouse production area. Boston ferns for indoor use are commonly greenhousegrown in 8-, 10-, or 12-inch plastic hanging baskets. The hanger assembly for the basket should be quick and easy to attach, and the hanger assemblies should be strong enough to support the weight of the mature crop without breaking. Plastic hanging baskets are offered for sale with either an internal water reservoir or an external, detachable saucer. Some growers prefer to remove external saucers during production to reduce the occurrence of waterlogged soil. Saucers are then re-attached prior to packing and shipping when the crop is sold.

\section{Potting Medium}

The potting media for growing Boston ferns should be well-aerated and well-drained. It should have a high waterholding capacity so that it will not dry out too rapidly. A medium composed of $50 \%$ peat, $25 \%$ perlite, and $25 \%$ vermiculite based on volume with a water-holding capacity by volume of $73 \%$ was used for producing quality 'Fluffy Ruffle' (Conover and Poole 1992). Many commercially prepared mixes sold by suppliers have characteristics necessary to produce a good crop. Growers should avoid using native soils in the potting media to prevent contamination from soilborne diseases, insects, and nematodes. The $\mathrm{pH}$ should be 5.0 to 5.5 .

\section{Irrigation}

Boston ferns should be watered by hand using a hose with a water breaker nozzle to settle the roots after initial planting. Plants grow most rapidly when medium is kept evenly moist but not saturated for a long period. During winter months, low light and cool temperature conditions can cause problems for young, recently potted plants. The grower should adjust watering requirements.

Large pots intended for landscape production and hanging baskets can be watered efficiently using micro-tube irrigation systems. Production areas designed for Boston fern hanging baskets frequently utilize automated timing systems and micro-tube irrigation. Small pots can be watered using sub-irrigation or by hand using a water breaker. Water application early in the morning is favorable to allow the foliage to dry during the day and prevent disease issues in fine-leaf, specialty varieties.

If plants are allowed to get too dry, the foliage of Boston fern develops a gray color and growth slows.

\section{Fertilization}

Newly potted liners should not be fertilized until the roots are well established. Liquid fertilization is the most common method of application in the production of small Boston fern varieties grown in small containers. Apply a low-ammonium formula at a rate of 150 to $175 \mathrm{ppm}$ nitrogen on a constant liquid feed basis using a fertilizer injector system. During warmer, brighter periods when growth is active, a 20-10-20 fertilizer may be used at 175 to $200 \mathrm{ppm}$ nitrogen. Where constant liquid feed is not available, 250-300 ppm nitrogen once per week works well.

Many growers of the large landscape varieties and hanging baskets incorporate slow release fertilizer into the soil mix at a rate recommended by the product manufacturer. 
However, lack of uniform mixing with the medium can be a problem. Growers may top dress large pots and hanging baskets with a slow release fertilizer such as Osmocote ${ }^{\circledast}$ or Nutricote ${ }^{\oplus}$ at the manufacturer's rate recommended for a particular pot size.

Growers are recommended to monitor media-soluble salts or electronic conductivity (EC) and $\mathrm{pH}$ every 2 or 3 weeks using the pour-through method of soil testing. If the soluble salts reading is $1 \mathrm{dS} / \mathrm{m}$, the plants will show nutrient deficiency if no additional fertilizer is provided. If the soluble salts reading is $2 \mathrm{dS} / \mathrm{m}$, nutrient levels are adequate; and if the reading is $3 \mathrm{dS} / \mathrm{m}$ or above, reduce either the rate or the frequency of fertilizer application. In some cases, leaching the media with water is necessary to reduce soluble salts buildup. Table 2 provides a guide for determining if Boston fern cultivars are appropriately fertilized based on leaf analysis.

\section{Light}

Boston ferns have a wide tolerance to changing light levels, but grow well when receiving 1,500 to $3,000 \mathrm{ft}-\mathrm{c}$, with best quality usually produced near 2,000 ft-c (Henley 1991). During the summer, high heat and high light intensity may need to be controlled. Light intensity can be reduced in the greenhouse by installing a $30 \%$ to $60 \%$ shade fabric. Too much light causes fronds to become light green in color. Light intensity that is too low results in elongated, weak fronds that are dark green in color but few in number.

\section{Temperature}

Suggested air temperature for producing Boston fern ranges from $65^{\circ} \mathrm{F}$ to $86^{\circ} \mathrm{F}$. The crop may tolerate slightly lower and higher temperatures depending on cultivars. Controlled environmental studies showed that maximum leaf area per frond, total frond area, and total dry weight were achieved with an average daily temperature of $75^{\circ} \mathrm{F}$ (Dawson et al. 1991). Growers producing hanging basket crops should be aware that greenhouse temperatures may stratify vertically. Temperatures where hanging baskets are located may be as much as 10 degrees warmer than at bench level.

\section{Shipping and Interior Care}

When smaller, more delicate frond varieties grown in small pots are pulled from shaded greenhouses for packing orders, care must be taken to avoid placing the pots into full sun on carts and loading docks. Sunburning can occur.

Finished plants should be groomed and packed by inserting individual plants into sleeves and placing the sleeved plants into appropriate boxes or cartons or onto structured racks for shipping. Sleeves are necessary because the fronds may break or tear.

Ferns should be transported in temperature-controlled trucks between $60^{\circ} \mathrm{F}$ to $65^{\circ} \mathrm{F}$ to avoid damage by both hot and cold temperature extremes especially during long distance shipping. Boston fern are fairly tolerant to ethylene.

Once arriving at their final destination after shipping, plants should be placed in interior light levels between 50 to 200 foot candles. Occasional grooming is needed to remove senesced fronds. Media should be kept slightly moist in interior conditions. Temperatures of $68^{\circ} \mathrm{F}$ to $75^{\circ} \mathrm{F}$ are most appropriate.

Larger Boston ferns for landscape installations should be sleeved and care should be taken not to crush plants when stacking into a truck. Plants should be installed as quickly as possible after arriving at the work site. Boston ferns will perform best in landscapes with partial to deep shade. Soil should be moist but well-drained. Plant on 12- to 24 -inch centers for quick establishment. Established beds can survive periodic bouts of dry weather. Light fertilization is recommended during the growing season followed by irrigation to wash granules off the fronds. Thick established clumps can be managed by severe pruning. New fronds quickly sprout from the roots.

\section{Physiological Problems}

Common physiological problems in Boston fern production and interiorscape usage are listed in Table 3. Most problems are related to poor management of water, nutrients, and improper use of chemicals.

\section{References}

Blaydes, G.W. 1940. "Evolution of Boston fern varieties." The American Biology Teacher. 2:145-146.

Chen, J., D.B. McConnell, D.J. Norman, and R.J. Henny. 2005. "The foliage plant industry." Horticultural Reviews. 31:45-110.

Conover, C.A., and R.T. Poole. 1992. "Effect of fertilizer and irrigation on leachate levels of $\mathrm{NH}_{4}-\mathrm{N}, \mathrm{NO}_{3}-\mathrm{N}$, and $\mathrm{P}$ in container production of Nephrolepis exalta 'Fluffy Ruffle." Journal of Environmental Horticulture. 10:238-241.

Conover, C.A., L.N. Satterthwaite, and K.G. Steinkamp. 1994. "Effects of controlled-release fertilizers containing a 
nitrification inhibitor on leachate characteristics." Proceed-

ings of Florida State Horticultural Society. 107:188-191.

Dawson, I.A., R.W. King, and R. van der Staay. 1991.

"Optimizing conditions for growth of Nephrolepis ferns."

Scientia Horticulturae. 45:303-314.

Griffith, L.P. 2006. Tropical Foliage Plants: A Grower's Guide.

Batavia, IL: Ball Publishing.

Henley, R.W., L.S. Osborne, and A.R. Chase. 1991. "Production Guide: Boston Fern." CFREC-Apopka Research Note RH-91-8.

Henny, R.J. and J. Chen. 2003. "Cultivar development of ornamental foliage plants." Plant Breeding Reviews. 23:245-290.

Hvoslef-Eide, A.K. 1991. "The effect of temperature, day length and irradiance on the growth of mother plants of Nephrolepis exaltata (L) Schott and on the subsequent growth in vitro runner tip explants." Scientia Horticulturae. 47: $137-147$.

Kessler, J. Raymond. 2004. "Greenhouse Production of Boston Ferns.” Extension sheet ANR-1095, Alabama Cooperative Extension System, Auburn, AL 36849.

Langeland, K.A. 2014. Natural area weeds: Distinguishing native and non-native 'Boston ferns' and 'Sword ferns (Nephrolepis spp.) AG120. Gainesville: University of Florida Institute of Food and Agricultural Sciences. http://edis.ifas. ufl.edu/ag120 
Table 1. Key characteristics of Boston fern cultivars currently in the market as of 2017.

\begin{tabular}{|c|c|}
\hline Cultivar & Characteristics \\
\hline Ariane & $\begin{array}{l}\text { A mutant selected from 'Fluffy Ruffles'. It has shiny, dark-green fronds and a slightly more upright growth habit } \\
\text { than its parent, and is suitable for a wide range of container or basket sizes. }\end{array}$ \\
\hline Boston Blue Bell & $\begin{array}{l}\text { Has a compact growth habit and can be grown and sold in smaller pot and basket sizes. It is one of the most } \\
\text { popular Boston fern cultivars in Europe. }\end{array}$ \\
\hline Bostoniensis & $\begin{array}{l}\text { This is the earliest selection of N. exaltata. It is a large fern that is more pendulous and graceful than the native } \\
\text { sword fern. }\end{array}$ \\
\hline Bostoniensis Compacta & This is an intermediate size fern. Its fronds are shorter, more compressed, and less pendulous than 'Bostoniensis'. \\
\hline Corditas & $\begin{array}{l}\text { Has sturdy, erect fronds that are close together and are densely covered with fine, dark-green leaflets. It is a fast- } \\
\text { growing cultivar with a maximum frond length of } 12 \text { inches }(30 \mathrm{~cm}) \text {. This dwarf fern is ideal for smaller pot sizes } \\
\text { and dish garden arrangements. }\end{array}$ \\
\hline Emina & $\begin{array}{l}\text { Displays dark green fronds maturing into crinkly/curly patterns. The fronds of this strong, compact cultivar } \\
\text { stand erect, and its slow growth habit makes it excellent for smaller pot sizes. This fern is suitable for } 3 \text { to } 6 \text { inch } \\
(7-15 \mathrm{~cm}) \text { containers and can commercially be grown with very close spacing. }\end{array}$ \\
\hline Nevada & $\begin{array}{l}\text { A mutant selected from 'Boston Blue Bell', 'Nevada' has much darker leaves than 'Boston Blue Bell'. Its leaves and } \\
\text { the leaflets are also wider and longer than the leaflets of 'Boston Blue Bell'. }\end{array}$ \\
\hline Pompom & $\begin{array}{l}\text { Has dark green fronds that form a very tight, full, rounded plant. Often used for dish gardens or in hanging } \\
\text { baskets. }\end{array}$ \\
\hline Tiger & $\begin{array}{l}\text { Fronds are long and pendulous, with a dark green coloring and gold variegation. Does well in shade with } \\
\text { regular water when grown in a basket. }\end{array}$ \\
\hline Fluffy Ruffles & $\begin{array}{l}\text { A compact cultivar with sturdy, erect fronds that reach a maximum length of } 12 \text { inches }(30 \mathrm{~cm}) \text {. The fronds are } \\
\text { dark green with an almost leathery texture. 'Fluffy Ruffles' is commonly grown in small pots or small baskets. }\end{array}$ \\
\hline
\end{tabular}

Table 2. Nutrient concentrations in leaves that are generally considered low, medium, or high for Boston fern (Nephrolepis exaltata 'Bostoniensis') growth (Conover et al. 1994).

\begin{tabular}{|c|c|c|c|}
\hline Nutrient & Low & Medium & High \\
\hline Nitrogen (\%) & $<2.0$ & $2.0-3.0$ & $>3.0$ \\
\hline Phosphorus (\%) & $<0.4$ & $0.4-0.8$ & $>0.8$ \\
\hline Potassium (\%) & $<2.5$ & $2.5-4.0$ & $>4.0$ \\
\hline Calcium (\%) & $<0.5$ & $0.5-2.0$ & $>2.0$ \\
\hline Magnesium (\%) & $<0.3$ & $0.3-1.0$ & $>1.0$ \\
\hline Sulfur (\%) & $<0.2$ & $0.2-0.6$ & $>0.6$ \\
\hline Iron (ppm) & $<150$ & $150-100$ & $>100$ \\
\hline Manganese (ppm) & $<50$ & $50-400$ & $>400$ \\
\hline Zinc (ppm) & $<30$ & $30-150$ & $>150$ \\
\hline Copper (ppm) & $<5$ & $5-10$ & $>10$ \\
\hline Boron (ppm) & $<30$ & $30-75$ & $>75$ \\
\hline
\end{tabular}

Table 3. Causes and treatments of various physiological problems (Henley et al. 1991).

\section{Symptom}

Graying - fern has gray cast with reduced growth rate and few runners

Weak fronds - plants have a reduced number of fronds and fronds that are long, weak, and pendulous.

Fronds become pale in color

Leaf tip and runners burn-frond tips and leaflets and runner tips turn brown and die.

\section{Probable Cause}

Plants have not received sufficient water, and growth rate and runner production decrease if potting medium is not consistently moist.

Low light levels.

Light levels are too high.

High media soluble salts or phytotoxicity caused by spraying chemicals

\section{Treatment}

Increase irrigation to supply sufficient water and keep media moist but not wet.

Increase light levels to reduce frond length and increase strength.

Decrease light levels to 2000 foot candles.

Leaching of media with good quality irrigation water and appropriate application of pesticides, fungicides, or bactericides. 